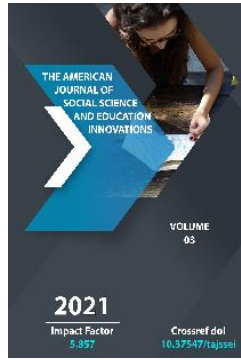

\title{
Competent Approach To Training Future Speech Therapists
}

\author{
Otabek Bozorov
}

Lecturer At The Tashkent State Pedagogical University, Tashkent, Uzbekistan

Journal Website:

http://usajournalshub.c

om/index,php/tajssei

Copyright: Original content from this work may be used under the terms of the creative commons attributes 4.0 licence.

\section{ABSTRACT}

A high-level professional can be considered a speech therapist who knows the norm! speech therapy correctional pedagogical activity, changes and develops his personality in the process of professional activity, the specificity of which is its multidisciplinary nature: a speech therapist works at the intersection of pedagogy, medicine, speech therapy, psychology and other scientific areas.

\section{KEYWORDS}

Speech therapist, teacher, learning process, inclusive education, outcome, competency approach.

\section{INTRODUCTION}

Realizing their functions in institutions of various profiles (preschool institutions for children with disabilities, specialized schools, speech centers at secondary schools, etc.), a speech therapist teacher deals with a large number of various signs of speech and psychophysical disorders. At the same time, carrying out corrective activities, the speech 
therapist teacher should contribute to the allround development of the child as a person for his adaggtashsh in society.

In professional pedagogy and psychology, the ability to isolate and successfully solve constantly emerging problems in a certain field of activity is considered as the professional thinking of a specialist. This fully applies to a teacher and therapist, who solves a complex of various kinds of professional problems; conducting a psychological and pedagogical examination, the use of differential diagnostics methods to determine the type of violation, the development of individual programs of correctional and pedagogical measures, ensuring the complexity of the impact on the speech pathologist, determining his real participation in this complex, etc. development of the child's personality, since speech disorders, limited verbal communication can cause mental layers, specific features of the emotional-volitional sphere.

\section{MATERIALS AND METHODS}

This professional posture is of particular importance in modern life, since most children with speech disorders have disharmonious personal development! \{uneven development of its individual aspects, violation of interpersonal relations, etc. p) Therefore, the effectiveness of influencing a child with a speech disorder is largely due to the normalization of his social contacts with people around him, the development of the emotional sphere, an increase in self-esteem, a positive self-concept, awareness of himself as a full-fledged member of society ... To solve the problems of the integral development of the personality of a child with speech pathology, a speech therapist must be ready to interact with other stages of the correction-development process (educators, subject teachers, psychologists, nurses, parents, etc.). This necessitates the formation of a speech therapist teacher's ability to formulate complex correctional and pedagogical tasks, to search for information for making competent systemic pedagogical decisions.

At the same time, an analysis of scientific publications and practice shows that in the process of solving professional problems, speech therapists face a number of problems in the implementation of the pedagogical aspects of their activities: difficulties are noted in organizing diagnostic measures, interpreting examination results in terms of taking into account the individual characteristics of the personality of a child with pathology. speech, determining the goals and correct directions of correctional-pedagogical influence and interaction with all subjects of the pedagogical process, implementation of a differentiated approach in drawing up individual plans for correctional measures, taking into account the personal characteristics of children-logopaths, etc.

\section{RESULTS AND DISCUSSION}

These difficulties are often caused by an insufficient level of development of the professional and pedagogical thinking of speech therapists, which does not allow them to fully isolate not only the psychophysiological problems of correctional speech therapy activity, but also its pedagogical aspect, which stimulates the process of individual development of a person with speech pathology as a person. 
This circumstance actualizes the need to increase attention to the development of professional and pedagogical thinking of future teachers of logopedists in the process of their professional training at a university. The scientific basis for solving this problem is the research of A.B. Brushliiskiy, L.S. Vygotsky, PL. Galperin, A.N. Leontiev, Ya.A. Ponomareva, S.L. Rubinstein, M.G. Yaroshevsky and others on the general theory of mppleniya, A.A. Batalova, D.N. Zavalishina, Yu.K. Kornilova, B.M. Teplova and others on the theory of professional thinking.

The works of these authors make it possible to analyze the processes of the formation of future speech therapists' ability to identify regular properties, cause-and-effect relationships and stable relationships of pedagogical phenomena; choose, compare, group the necessary information to solve professional problems. Studies devoted to the formation of pedagogical thinking (N.V. Kuzmina, M.M. Kashapov, E.K. Osipova, AA Orlov, Yu.V. Senko, V.A. aspect of professional thinking of a speech therapist. They note that the leading professional characteristics of the thinking of a modern teacher are his axiological orientation, creativity, anxiety and criticality. It is the axiological component that allows the teacher not only to analyze the emerging situation, but to understand and accept it, which is the most important condition for isolating the pedagogical problem and determining the optimal ways and means of solving it.

The educational process of a modern university, which trains teachers of logopedists, has great opportunities for the development of professional and pedagogical development of future specialists. A significant role in its development is played by disciplines of subject training, which, on the basis of integration with psychological and pedagogical subjects, are designed to provide a deep theoretical understanding of the foundations of the professional activity of a speech therapist and to form his readiness to formulate and solve correctional and pedagogical tasks. In the process of studying them, professional and pedagogical knowledge is systematized and acquired, intelligence is formed, the skills of the future professors' teacher-speech therapist are improved. However, to a lesser extent! the content of disciplines of subject training reflects on an interdisciplinary and intradisciplinary basis the emotional and value aspect of the professional activity of a speech therapist, the implementation of which allows future specialists to form an idea of the main purpose and purpose of the correctional pedagogical process - the integral development of the personality of a child with speech impairment.

However, the problem associated with the development of professional and pedagogical confusion of speech therapists in the process of studying subject training disciplines has not been adequately reflected in scientific research, which creates difficulties in creating scientific and methodological support for this process in a university. Thus, we can state the contradictions between:

- The objective need for high-quality training of teachers-speech therapists who are able to solve a variety of multifunctional correctional-pedagogical tasks and the real state of training speech therapy personnel in universities; 
- The need for the development of professional and pedagogical thinking of future speech therapists in the process of vocational training at a university in the study of subject training disciplines and insufficient scientific and methodological support of this process.

\section{CONCLUSION}

These contradictions determine the problem of research, what should be the content and technology of studying disciplines of subject training in a university, in order to productively develop the professional and pedagogical thinking of future speech therapists in the process of studying them. The need to resolve the indicated problem led to the choice of the topic of the dissertation research: "Development of professional and pedagogical thinking.

\section{REFERENCES}

1. Polat E.S., Bukharkina M.Yu. Modern pedagogical and information technologies in the education system: textbook. manual for stud. universities. 2nd ed., Erased. Moscow: Academy, 2008.368 p.

2. Chukhacheva E.V. Formation of the readiness of future teachers for the development of monologue speech of preschool children in the educational process of the university: author. diss. ... Cand. ped. sciences. Bryansk, 2012.23 p.

3. Levchenko I.E., Zabramnaya S.D. Psychological and pedagogical diagnostics.-M .: "ACADEMIA", 2005 th.
4. Nurkeldieva D.A. Pedagogical psychologist diagnostics. T.: "VNESHINVESTPROM", 2019 st.

5. Diagnostics of mental development in early childhood. Authors-compilers: R.K.Aitzhanova, R.A. Sulaimenova, A.K. Ersarin and others. Almaty, 2000.

6. Muminova L.R., Amirsaidova Sh. and others. Special psychology. T.: "National Society of Philosophers of Uzbekistan", 2013. 